https://helda.helsinki.fi

\title{
The "Thick" Rule of Law and Mutual Trust in the European Union
}

Raitio, Juha

2020-12

Raitio , J 2020 , ' The "Thick" Rule of Law and Mutual Trust in the European Union ', Baltic yearbook of international law online , vol. 18 , no. 1, pp. 1-17 . https://doi.org/10.1163/22115897_01801_002

http://hdl.handle.net/10138/328671

https://doi.org/10.1163/22115897_01801_002

unspecified

acceptedVersion

Downloaded from Helda, University of Helsinki institutional repository.

This is an electronic reprint of the original article.

This reprint may differ from the original in pagination and typographic detail.

Please cite the original version. 
Juha Raitio

Professor of European Law

University of Helsinki

e-mail: Juha.Raitio@helsinki.fi

13 December 2019

BYIL

\section{The "Thick" Rule of Law and Mutual Trust in the European Union}

Abstract:

The concept of Rule of law has become a topical and controversial issue lately. For example, the existence of effective judicial review is an inseparable part of the rule of law and some problems in this respect has been analysed. This article advocates for a thick concept of rule of law, which refers to the idea that rule of law has both material and formal content. The controversial part seems to be the question of material content and whether it obscures the essential meaning of the rule of law as a requirement of legality. However, the material aspect of rule of law can be linked to the value-base of the European Union. For example, during its EU Presidency, Finland has strongly emphasised the significance of the value base and rule of law in Article 2 TEU for the development of the EU. ${ }^{1}$ Democracy, the rule of law, and the actualisation of fundamental and human rights in particular are connected together into a trinity where all the components form preconditions for the others. This stance is not a novelty in Finland, since Jyränki, for one, has already two decades ago maintained that that human rights protect the individual's position and thus belong to the sphere of material concept of rule of law. ${ }^{2}$ I have employed the metaphor of a musical triangle. A triangle can only make a sound if all three of its corners are connected to each other, thereby connecting the sides of the triangle. The observance of the core values of the EU is a precondition for the mutual trust between Member States, which in turn is necessary for the well-functioning European union and good governance. Mutual trust is further analysed in the light of the case law, which often relates to the area of freedom, security and justice.

\footnotetext{
${ }^{1}$ Presidency conclusions, Council document 12044/19 and e.g. the home pages of the president state www.eu2019.fi.

2 See Jyränki, A (2002) 'Oikeusvaltio ja demokratia' in A Aarnio and T Uusitupa (eds), Oikeusvaltio (Helsinki, Lakimiesliiton kustannus) 23. Antero Jyränki is the former professor of Constitutional law of the University of Turku.
} 


\section{The Material and Formal Elements of Rule of Law}

Let's start by trying to define the concept of rule of law, although an attempt to define it is most likely doomed to fail at least to a certain extent. The rule of law is associated with the deepest layers of law, the layer of moral considerations. ${ }^{3}$ It represent the fundamental and unwaivable values of the Member States and relate, therefore, to both legal culture and legal norms. ${ }^{4}$ Another starting point is that rule of law is not only a formal principle. In contemporary legal literature especially in the field of EU law one can refer to the "thick" conception of rule of law, which contains both formal and material elements. ${ }^{5}$ The protection of individual rights seems to strengthen the interpretation of "thick" rule of law. ${ }^{6}$

Based on legal literature, the "thick" concept of rule of law seems to be controversial, especially with regard to how the material dimension of the concept of rule of law should be regarded. In Sweden, already in the 1990s Frändberg has described the concept of rule of law as a "rhetorical balloon" that one can, in a way, fill up, including in it everything possible that is felt to be positive. ${ }^{7}$ Frändberg's argument reflects a fear according to which the rule of law is in danger of becoming blurred as a concept and losing some of its expressiveness, if it is interpreted too broadly. In his more recent works he has studied "law-state thinking" and clarified his idea of "watering-down of language". According to him this tendency manifests itself mainly in the smoothing over of tensions and conflicts between different values and principles. He finds that by including two or more different values or principles in one and the same concept one hides the fact that they might be potentially contradictory. He

\footnotetext{
${ }^{3}$ See e.g. Raitio J (2003) The Principle of Legal Certainty in EC Law, (Dordrecht, Kluwer Academic Publishers), 301 304 and Klami, H T (1994) Methodological Problems in European and Comparative Law, (Helsinki, University Press), 10-12.

${ }^{4}$ See Tuori, K (2007) Oikeuden ratio ja voluntas, (Helsinki, WSOYpro) 222 and Tuori, K (2011) Ratio and Voluntas, The Tension Between Reason and Will in Law (Farnham, Ashgate) 208. Tuori has somewhat similarly separated the Constitution into explicit, written norms and constitutional culture, which refers to constitutional theories, concepts and principles, as well as ways of dealing with these, i.e. patterns of constitutional argumentation.

5 See e.g. Pech, L (2013), Promoting the rule of law abroad: on the EU's limited contribution to the shaping of an international understanding of the rule of law, in Kochenov, D-Amtenbrink, F (eds.) EU's Shaping of the International Legal Order, (Cambridge, Cambridge University Press), 108-129 or McCorquodale, $R$ (2016), Defining the International Rule of Law: Defying Gravity?, International \& Comparative Law Quarterly, part 2, 277-304, at 284-285 (McCorquodale 2016): "Thus the approach taken in this article is to define the international rule of law in terms of the objectives of a rule of law Defining the International Rule of Law, and thereby provide a definition appropriate to the distinctive nature of the international system. The definition offered in this article of the international rule of law is a "thick" one and includes the following elements or objectives: legal order and stability; equality of application of the law; protection of human rights; and the settlement of disputes before an independent legal body".

${ }^{6}$ See e.g. Von Bogdandy, A - Antpöhler, C - Ioannidis, M (2017), Protecting EU values, Reverse Solange and the Rule of Law Framework, in Jacab, A - Kochenov, D (eds), The Enforcement of EU law and Values, (Oxford University Press) 218-233, at 226 (Von Bogdandy - Antpöhler-Ioannidis 2017).

7 See Frändberg, § (1996) 'Begreppet rättsstat', in F Sterzel (ed), Rättsstaten - rätt, politik, moral, (Stockholm, Rättsfonden) 21-41, at 22-23.
} 
advocates for a "minimal law state-thinking" in which only a few narrowly defined values are defined and applied in practice. ${ }^{8}$ In the same tone $R a z$ has warned against confounding the concept of rule of law with a wide range of values, principles or goals that are characteristic of a good legal system. ${ }^{9}$ Although I agree that the concept of rule of law is ambiguous, I think that a legal interpretation is always contextual in such a way that labelling the concept of rule of law as a rhetorical balloon is hyperbole.

I think it is important to note that merely democratic legitimacy for legislation is not enough, since some sort of substantive acceptability for the legal rules is also a prerequisite for the legitimacy. This kind of demand of substantive acceptability of law is obviously difficult to define or describe, but I think Fuller has succeeded in illustrating the main features of it by telling a fascinating allegory of King Rex, who failed to make law in eight different ways. ${ }^{10}$ For example, laws can't be obscure or require an impossibility. They can't be changed frequently, since the lack of stability causes many problems. They can't be made to contradict each other, i.e. one rule may not allow something that another one prohibits. This reference to Fuller is not as novel idea as it may seem, since Kilpatrick has recently referred to Fuller in her article, which relates to the managerialism connected to the taming of the sovereign debt crisis in the EU. ${ }^{11}$ So I think that trying to define rule of law is not merely waste of time, but instead it seems to be an always topical task, which is worth studying from various angles. Having stated my inclination to rely on the "thick" concept of rule of law let's consider, how the rule of law can be perceived in the EU law.

\section{Rule of Law, Judicial Review, Adequate Reasoning and the Independence of the Judiciary}

Already before the principle of rule of law was separately mentioned in the EU Treaty, the European Court of Justice stated already in 1986 in its Les Verts judgment that the then European Economic

\footnotetext{
${ }^{8}$ See Frändberg, Å (2014) From Rechtsstaat to Universal Law-State, An Essay in Philosophical Jurisprudence, (Dordrecht, Springer) 30-32.

${ }^{9}$ See Raz, J (1979) The Authority of Law, Essays on Law and Morality, (Oxford, Clarendon Press) 211.

${ }^{10}$ Ks. Fuller, L L (1969) The Morality of Law (New Haven and London: Yale University Press) 33-38. King Rex wanted to reform his administration of justice, which was expensive, the judges were slow and corrupted, and the language used in court was old-fashioned and clumsy. As a solution, legislator and monarch Rex stipulated that all laws were to be abolished. Thereafter, the administration of justice was based on ad hoc judgments, which in the long run were due to form legal praxis that would guide the administration of justice. Judgments could not, however, be generalized in this way without legislation existing in the background, so the reform project was not successful. He decided to make seven other alterations, which all turned out to be failures.

${ }^{11}$ Ks. Kilpatrick, C (2015) 'On the Rule of Law and Economic Emergency: The Degradation of Basic Legal Values in Europe's Bailouts’ Oxford Journal of Legal Studies 345-347.
} 
Community is a community of law, because both its Member States and its institutions are under supervision aimed at compatibility between measures implemented by them and the document corresponding to the Constitution, i.e. the EU Treaty. ${ }^{12}$ The Les Verts case essentially involved the implementation of the requirement for an effective legal remedy in connection with an action for annulment. As a registered political party Les Verts (parti écologiste) was a legal person and not just an open category of indeterminate group of citizens. The applicant had no other alternative remedy. It was held in the judgment that the decision by the European Parliament may be appealed despite the fact that the European Parliament was not mentioned in Article 263 TFEU concerning annulment. Rule of law thought is illustrated by the fact that all acts of the EU institutions that produced legal effects had to be subject to judicial oversight.

In the same tone, the Court of Justice has stressed in its subsequent case law that access to justice i.e. right to an effective judicial remedy may play a significant role when it determines the locus standi in the framework of Article 263 TFEU. However, right to an effective judicial remedy is not a like trump card, which always win, since procedural prerequisites must be taken into consideration and this is surely not against the rule of law. For example, the former Court of the First Instance held the application in the Greenpeace case ${ }^{13}$ inadmissible, since none of the members of the Greenpeace organisation in question could claim to have been directly and individually concerned as required in the Article 263 TFEU. On the other hand, bearing in mind the contemporary political climate as regards the protection of environment and horizontal Article 11 TFEU one might wonder, whether the Courts position would be less restrictive today. In the field of environmental law the requirement of direct and individual concern makes it inherently difficult to provide adequate judicial review against EU actions affecting the environment. In this context it is also relevant to note that the preliminary rulings procedure is not to be used as a substitute for actions of annulment based on the Article 263 TFEU, although the timeframe of 2 months is relatively short for initiating proceedings. ${ }^{14}$

The Court of Justice has also underlined that legal decisions must contain adequate reasons so that the addressee of the decision is able to determine, whether the decision contains a defect allowing its legality to be challenged. ${ }^{15}$ This demand of adequate reasoning can be linked to principles of good (sound) administration, legal certainty as well as rule of law. However, one may pose a question,

\footnotetext{
12 See 294/83 Parti écologiste "Les Verts" v. the European Parliament (1986) ECR 1339, para 23.

${ }^{13}$ See T-585/93 Greenpeace (1995) ECR II-2205 and the affirmation of the position adopted in the case C-321/95 P, Greenpeace (1998) ECR I-1651.

${ }^{14}$ See e.g. C-188/92 TWD (1994) ECR I-833, para. 24.

${ }^{15}$ See e.g. 69/83 Lux (1984) ECR 2447, paras. 32-36.
} 
whether the reasoning of the Court of Justice is always satisfactory from the perspective of various stakeholders or other courts. For example, in the Ajos-case. ${ }^{16}$ the Danish Supreme court did not accept the Court's reasoning as regards discrimination on grounds of age in the context of the case. In the Ajos -case, however, I don't find the reasoning of the Court of Justice to be inadequate.

For me the problem of inadequate reasoning relates the competition law cases in which the level of fines is at hand. ${ }^{17}$ The Commission's wide-scale discretion in the determination of competition fines came to the fore at the beginning of the millennium, since the likely fines were 1000 euros to 1 million euros in the case of minor infringements and from 1 to 20 million euros in serious infringements on grounds of the then valid guidelines. ${ }^{18}$ Such a scale offered too much discretion in my opinion, although it seems that the Court of Justice has had a different stance on this. ${ }^{19}$ It is not at all unusual that the level of competition fines continues to cause legal debate even today, since even the contemporary guidelines are relatively obscure as well. ${ }^{20}$ Article 23(4) of the Regulation 1/2003 simply imposes a rigid upper limit for fines imposed by Commission, namely $10 \%$ of the total turnover of the undertaking concerned in the preceding business year. The basic amount of the fine will be related to a proportion of the value of sales, depending on the degree of gravity of the infringement, multiplied by the number of years of infringement. ${ }^{21}$ As an example, one can refer to the Commission's so-called tax planning practices in State Aid cases. ${ }^{22}$ From the perspective of legal certainty and the principle of proportionality, it is interesting that the EU General Court has lately made the competition fines ordered by the Commission more reasonable due to their incorrectly

\footnotetext{
${ }^{16}$ See the ECJ case C-441/14 Ajos, ECLI:EU:C:2016:278 as well as articles Neergaard, U \& Engsig SØrensen, K (2017) 'Activist Infighting among Courts and Breakdown of Mutual Trust? The Danish Supreme Court, the CJEU, and the Ajos Case' Yearbook of European Law 1-39 and Nielsen, R \& TvarnØ, C (2017) 'Danish Supreme Court Infringes the EU Treaties by Its Ruling in the Ajos Case' Europarättslig Tidskrift, 303-326, at 303, in which it has been stated: "In its judgment in the Ajos-case, the Court of Justice of the European Union (CJEU) upheld its findings in Mangold and Kücükdeveci. The Danish Supreme Court defied the CJEU and did the opposite of what the CJEU had held it was obliged to do".

${ }^{17}$ See e.g. Raitio J (2018), Rule of Law, Legal Certainty and Efficiency in EU Competition Law, Rechtstheorie, 479-495.

${ }^{18}$ See e.g. the Guidelines on the method of setting fines imposed pursuant to Article 15(2) of Regulation N:o 17 and Article 65 (5) of the ECSC Treaty, OJ, No C 9, 14th January 1998, p. 3.

${ }^{19}$ See e.g. C-501/11 P, Schindler, ECLI:EU:C:2013:522, paras. 58, 59 and 75.

${ }^{20}$ See Council Regulation (EC) No 1/2003 of 16 December 2002 on the implementation of the rules on competition laid down in Articles 81 and 82 of the Treaty, OJ, N:o L 1, p. 1 and the Opinion of Advocate -General Wahl in case C-617/17 Powszechny Zakład Ubezpieczé́ na Życie S.A. v Prezes Urzędu Ochrony Konkurencji i Konsumentów, ECLI:EU:C:2018:976, paras. 56-57 and the ruling of the case C-617/17 Powszechny Zakład Ubezpieczeń na Życie S.A.v Prezes Urzędu Ochrony Konkurencji i Konsumentów ECLI:EU:C:2019:283, paras. 37-39.

${ }^{21}$ See Guidelines on the method of setting fines imposed pursuant to Article 23(2)(a) of Regulation No 1/2003, para. 19, OJ, No C 210, 1 September 2006, p. 2.

${ }^{22}$ See Commission's decision SA.38375, FIAT, Commission's decision SA.38374, Starbucks and Commission's decision SA.38373, Apple.
} 
defined subjective gravity, which in turn is related to inadequate reasoning at least to a certain extent. $^{23}$

Judicial review and it's relation to rule of law has therefore not that clearly been stressed in the older case law, whereas in more recent case law the connection between judicial review and rule of law has been expressed clearly in the wording of the reasoning. ${ }^{24}$ For example, in Rosneft the Court stated as follows:

"It may be added that Article 47 of the Charter, which constitutes a reaffirmation of the principle of effective judicial protection, requires, in its first paragraph, that any person whose rights and freedoms guaranteed by EU law are violated should have the right to an effective remedy before a tribunal in compliance with the conditions laid down in that article. It must be recalled that the very existence of effective judicial review designed to ensure compliance with provisions of EU law is of the essence of the rule of law."25

Nowadays, the rule of law is rather often seen in EU law to have material content, which partially explains the fact that the rule of law has begun to be applied as a legal settlement argument in EU courts. As a practical example, the Court has had to take a stance in defence of the rule of law, especially in contexts relating to the impartiality of the courts. ${ }^{26}$ For example, in the relatively recent case law the Court has stressed the importance of the independence of the judicial systems in the following way:

"In that regard, it must be pointed out that the requirement of judicial independence forms part of the essence of the fundamental right to a fair trial, a right which is of cardinal importance as a guarantee that all the rights which individuals derive from EU law will be protected and that the

\footnotetext{
${ }^{23}$ See, for example, T-418/10 Voelstalpine, ECLI:EU:T:2015:516 and T-389/10 and T-419/10 Siderurgina Latina Martin, ECLI:EU:T:2015:513.

${ }^{24}$ See C-562/13 Abdida, ECLI:EU:C:2014:2453, para. 45, C-362/14 Schrems, ECLI:EU:C:2015:650, para. 95 and C72/15 Rosneft, ECLI:EU:C:2017:236, para. 73.

${ }^{25}$ See C-72/15 Rosneft, ECLI:EU:C:2017:236, para. 73.

26 See e.g. case Portuguese judges C-64/16 Associação Sindical dos Juízes Portugueses v. Tribunal de Contas, ECLI:EU:C:2018:117, section 30, 36 and the issues concerning Poland C-216/18 PPU, LM, ECLI:EU:C:2018:586, section 48, C-619/18, Commission v Poland, ECLI:EU:C:2018:910, section 21, C-619/18 R, Commission v. Poland, ECLI:EU:C:2018:1021, C-192/18 Commission v Poland, ECLI:EU:C:2019:924 and in the context of Article 4(2) TEU in C-715/17 Commission v Poland, ECLI:EU:C:2019:917, paras. 224-227, (Opinion of Advocate General Sharpston delivered on 31 October 2019). Claims relating to the rule of law are pending for Hungary, referring here to cases C-78/18 Commission v. Hungary, C-66/18 Commission v. Hungary and C-718/17 Commission v. Hungary.
} 
values common to the Member States set out in Article 2 TEU, in particular the value of the rule of law, will be safeguarded."27

Thus it is safe to conclude the existence of effective judicial review is an inseparable part of the rule of law. ${ }^{28}$ It is also relevant to point out that the Commission has initiated the proceedings specified in Article 7(1) TEU against Poland in December 201729, and the Parliament did the same with Hungary in September 2018. ${ }^{30}$ In legal literature this Polish and Hungarian development has recently been called as "illiberal democracy".31

\section{The Triangle of Rule of law, Democracy and Human Rights}

Another aspect of this discussion based on EU law is the relationship between rule of law, democracy and human rights. This European "triangle of values" is not a novelty at all. For example, one can refer to the following citation from a German legal theorist Radbruch:

"Though democracy is certainly a praiseworthy value, the Rechtstaat is like a daily bread, the water we drink and the air we breathe; and the greatest merit of democracy is that it alone is adapted to preserve the Rechtstaat". 32

A bit later Hayek has not only referred to this sentence by Radbruch but also added that democracy will not exist long unless it preserves the rule of law. ${ }^{33}$

As far as the European union and its values are concerned, it is relevant to point out that observing the rule of law is also a condition for being a member of the European Union. In 1993, the European Council clarified the conditions that countries seeking EU membership must fulfil. In accordance

\footnotetext{
${ }^{27}$ See C-216/18 PPU, LM, ECLI:EU:C:2018:586, para. 48 and C-619/18, Commission v Poland, ECLI:EU:C:2018:910, para. 21.

${ }^{28}$ See C-72/15 Rosneft, ECLI:EU:C:2017:236, para. 73 and C-64/16 Associação Sindical dos Juizes Portugueses v. Tribunal de Contas, ECLI:EU:C:2018:117, para. 36.

${ }^{29}$ See Proposal for a Council Decision on the determination of a clear risk of a serious breach by the Republic of Poland of the rule of law, COM (2017) final.

${ }^{30}$ See European Parliament resolution of 12 September 2018 on the proposal calling on the Council to determine, pursuant to Article 7(1) of the Treaty of European Union, the existence of a clear risk of a serious breach by Hungary of the values on which the Union is founded, 2017/2131 (INL).

${ }^{31}$ See e.g. Bugariĉ, B. (2016) 'Protecting Democracy inside the EU: On Article 7 TEU and the Hungarian Turn to Authoritarianism', in C Closa and D Kochenov (eds), Reinforcing Rule of Law Oversights in the European Union, (Cambridge, Cambridge University Press) 82-101.

${ }^{32}$ See Radbruch, G (1950) Rechtsphilosophie (Stuttgart, K.F. Köhler) 357.

${ }^{33}$ See Hayek, F A (1960) The Constitution of Liberty (London, Routledge \& Kegan Paul) 248
} 
with these so-called Copenhagen criteria, all European countries that adhere to the principles of freedom, democracy, human rights, respect for fundamental freedoms and the rule of law may apply for membership. Today, respecting the principle of rule of law as condition for membership is manifested in the Treaty, because in accordance with Article 49 TEU, a European state that respects and promotes values defined in Article 2 TEU can apply for membership to the European Union. ${ }^{34}$ It is characteristic of the EU legal concept of rule of law to include, as Article 2 TEU does, ${ }^{35}$ democracy, human rights, equality and the concept of rule of law as part of the same entity, which is aptly described by the following quote from the Kadi case:

"It is also clear from the case-law that respect for human rights is a condition of the lawfulness of Community acts (Opinion 2/94, paragraph 34) and that measures incompatible with respect for human rights are not acceptable in the Community". ${ }^{36}$

Therefore, there are indications in the case law of the Court of Justice that in its legal context, the concept of rule of law includes certain material prerequisites for legal decision-making. ${ }^{37}$

In addition, there is reason to highlight the procedure of Article $7 \mathrm{TEU}^{38}$ to oversee the integrity of values in accordance with Article 2 TEU from the perspective of EU law and the operating framework of the Commission published in 2014, with which systemic i.e. system-level threats are tackled in the Member States. ${ }^{39}$ From a wider European viewpoint, the framework, for its part, is meant to advance the achievement of the goals of the Council of Europe and also take into account the expertise and views of the European Commission for Democracy through Law i.e. the so-called Venice Commission on the principle of rule of law. In its report, the Venice Commission lists the following factors included in the concept of rule of law:

\footnotetext{
34 See e.g. C-621/18 Wightman, ECLI:EU:C:2018:999, paras. 62-63.

35 Article 2 TEU: "The Union is founded on the values of respect for human dignity, freedom, democracy, equality, the rule of law and respect for human rights, including the rights of persons belonging to minorities. These values are common to the Member States in a society in which pluralism, non-discrimination, tolerance, justice, solidarity and equality between women and men prevail."

${ }^{36}$ See C-402/05 P and C-415/05 P, Kadi and Al Barakaat (2008) ECR I-6351, para 284 and also correspondingly C112/00 Schmidberger (2003) ECR I-5659, para 73.

${ }^{37}$ See 8/55 Fédéchar (1955) ECR 292, especially p. 299 and cases related to the concept of rule of law concerning EU law's external liability 5/71 Schöppenstedt (1971) ECR 975, 59/72 Wünsche Handelsgesellschaft (1973) ECR 791, 20/88 Roquette frères (1989) ECR 1553, C-152/88 Sofrimport (1989) ECR I-2477, C-104/89 and C-37/90 Mulder (1992) ECR I-3061 and C-282/90 Vreugdenhill (1992) ECR I-1937.

${ }^{38}$ See, for example, T-337/03 Bartelli Gálves v. The Commission (2004) ECR II-1041, which concerned the procedure of then Article 7 EU now Article 7 TEU.

${ }^{39}$ See the Commission's Communication to the European Parliament and Council, A new EU operating framework for strengthening the principle of rule of law, COM (2014) 158 final.
} 
-principle of legality, which refers to the transparency, accountability, democratic nature and pluralism of the legislative process

-legal certainty ${ }^{40}$

-prohibition of arbitrariness of the executive powers

-access to justice in independent and impartial courts

-effective judicial review, which includes respect for fundamental and human rights, and

-equality before the law. ${ }^{41}$

The Commission's operating framework and the work of the Venice Commission have not been unimportant, because in January 2016 the Commission began a dialogue with Poland in accordance with the operating framework due to problems related to the position of the Constitutional Court. ${ }^{42}$ These elements of rule of law listed by the Venice Commission has also been brought up in the Commission communication dated 3 April 2019. ${ }^{43}$

A fairly unambiguous interpretation can be read of the Communication concerning the operating framework, according to which in EU law, the rule of law is a constitutional principle formed of factors concerning both form and content. ${ }^{44}$ According to the Communication, this means that adhering to the principle of rule of law is essentially connected to the respect for democracy and human rights in such a way that democracy cannot exist and human rights cannot be respected if the principle of rule of law is not adhered to. ${ }^{45}$ It is also central to state that the trust of EU citizens and

\footnotetext{
${ }^{40}$ See an attempt to define legal certainty in e.g. Raitio 2003, p. 387: "The principle of legal certainty in EC law relates to the principle of non-retroactivity and the protection of legitimate expectations in particular, but more profoundly it can be related to the conceptual scale for weighing up and balancing between predictability and acceptability, between formal justice and material fairness, in legal decision-making".

${ }^{41}$ See European Commission for Democracy Through Law (Venice Commission), Report on the Rule of Law, Adopted by the Venice Commission at its 86th plenary session, Venice 25-26 March 2011, Strasbourg, 4 April 2011 , Study No. 512/2009, CDL-AD (2011)003rev., para 41.

${ }^{42}$ See the Commission's recommendation (EU) 2016/1374, delivered on 27 July 2016, on adhering to the principle of rule of law in Poland, EUVL, No L 217, 12 August 2016, pp. 53-68, (C/2016/5703), which has a reference to the Venice Commission's definition of the principle of rule of law in section 5 of the Introduction.

${ }^{43}$ See Communication from the Commission: Further strengthening the rule of law within the European Union, COM (2019) 163 final., p. 1-2.

${ }^{44}$ In support of the interpretation concerning both the formal and material dimension of the concept of rule of law see, for example, C-50/00 P, Unión de Pequeños Agricultores (2002) ECR I-6677, paras 38 and 39 as well as C-402/05 P and C-415/05 P, Kadi and Al Barakaat (2008) ECR I-6351, para 316. A corresponding policy on the substantive and material dimension of the principle of rule of law is also included in the case law of the European Court of Human Rights, on which see Stafford v. the United Kingdom, Judgement of 28 May 2002 (Application no. 46295/99), para 63.

${ }^{45}$ See, for example, Broekman, J M (1999) The Philosophy of European Union Law, (Leuven, Peeters) 205.
} 
national authorities in the realization of the rule of law in other Member States is important, so that the EU can act as a "region of freedom, law and security that does not have internal borders". 46

This mutual trust among the Member States has also received an especially prominent role in Opinion 2/13 by the Court of Justice of the EU. ${ }^{47}$ Similarly to the Court of Justice of the EU, with regard to the trust among the Member States, we should emphasize that all of the Member States comply with Union law, especially with the fundamental rights recognized in EU law. ${ }^{48}$ The concept of rule of law thus receives interpretive content in EU law only in connection to how democracy and fundamental rights are realized and how the Member States can trust each others' legal systems.

As a counter-argument to this contextual and fairly broad interpretation of the concept of rule of law we can return to the argument, according to which the rule of law is in danger of becoming blurred as a concept and losing some of its expressiveness. Thus if the concept of rule of law in a European context can be understood in relation to fundamental and human rights and democracy, then what is the content of its meaning and is the consideration of a material and formal concept of rule of law a relevant question anymore? My interpretation is that the contextual interpretation of the concept of rule of law in relation to, for example, fundamental and human rights, does not exclude assessing what elements constitute the rule of law.

\section{Mutual Trust or Blind Trust?}

The trust of EU citizens and national authorities in the implementation of other member states' rule of law is important, in order for the EU to achieve its key objectives and operate as a supranational legal system, where the enforcement of EU law is mainly executed by the member states' authorities. ${ }^{49}$ Mutual trust has been seen to be a prerequisite for good governance. ${ }^{50}$

\footnotetext{
${ }^{46}$ See COM (2014) 158 final, para 2,"Why the principle of rule of law is decisively important for the EU".

${ }^{47}$ See Opinion 2/13, Opinion delivered pursuant to Article 218(11) TFEU, delivered on 18 December 2014, not published in the ECR, paras 168,191,192 and 258. The Court of Justice of the EU held that the planned agreement for the EU to join the European Convention on Human Rights is not in conformity with Article 6(2) TFEU or Protocol No. 8 EU, because, for example, it does not prevent the danger that the principle of mutual trust that exists among Member States in EU law can be infringed.

${ }^{48}$ Ibid., para 191.

${ }^{49}$ See committee's briefing to the European Parliament and Council of Europe, New EU operational framework for strengthening the rule of law, COM (2014) 158 final, Section 2,"Why is the rule of law of fundamental importance to the EU".

${ }^{50}$ See Cramér, P (2009), Reflections on the Roles of Mutual Trust in EU law, in publication Dougan, M - Currie, S (eds.): 50 Years of the European Treaties, Looking Back and Thinking Forward, (Oxford, Hart Publishing) 43-61.
} 
Thereafter the principle of mutual trust has caused academic debate about, what it means and how it can be achieved. ${ }^{51}$ According to Opinion 2/13, mutual trust can be associated with the specificities of European Union Law. First of all, EU law is based on an independent source of law formed by framework agreements, which has a primality in relation to the member states' law. ${ }^{52}$ The key characteristics of the union's law have formed a basis for the creation of a network of such principles, rules and legal relations which have a mutual dependency, which reciprocally binds the union itself and its member states. The European Union is built on the understanding that each member state shares several mutual values with all the other member states, as described in TEU Article 2. This starting point of mutually acknowledged values justifies that mutual trust can prevail between member states. A legal structure as such also includes fundamental rights as they have been recognised in the EU Charter of Fundamental Rights, and which are interpreted in accordance with the Union's structure and objectives. ${ }^{53}$

The citation of Section 191 in Opinion 2/13 summarises the above-mentioned ideology and also demonstrates the significance of mutual trust as follows:

"In the second place, it should be noted that the principle of mutual trust between the Member States is of fundamental importance in EU law, given that it allows an area without internal borders to be created and maintained. That principle requires, particularly with regard to the area of freedom, security and justice, each of those States, save in exceptional circumstances, to consider all the other Member States to be complying with EU law and particularly with the fundamental rights recognised by EU law". ${ }^{4}$

In the above cited Section 191 of Opinion 2/13, the Court of Justice of the European Union (CJEU) referred to its previous legal praxis, i.e. the N.S. and Melloni cases ${ }^{55}$, which is necessary particularly in demonstrating, when exceptions can be made to the principle of mutual trust. Lenaerts has had

\footnotetext{
${ }^{51}$ See e.g. Bieber, $R$ (2015), “Gegenseitiges Vertrauen” zwischen den Mitgliedstaaten - ein normatives Prinzip der Europäischen Union?, in publication Epiney, A - Affolter, S (Hrsg.): Die Schweiz und die Europäische Integration: 20 Jahre Institut für Europarecht, Schulthess, $37-55$ (Bieber 2015) and Farturova, M (2016), La Coopération Loyale vue sous le Prisme de la Reconnaissance Mutuelle: Quelques Réflexions sur les Fondaments de la Construction Européenne, Cahiers de Droit Européen, 193-219. The connection between the principle of mutual trust and the principle of sincere cooperation or loyalty is one further argument to justify it.

52 See 6/64 Costa v ENEL (1964) ECR 585.

${ }^{53}$ See Opinion 2/13, statement issued under TFEU Article 218 Section 11, issued on 18th December 2014, not published in the ECR, ECLI:EU:C:2014:2454, Sections 166-171.

${ }^{54}$ Ibid, Section 191.

${ }^{55}$ See C-411/10 \& C-493/10 N.S. (2011) ECR I-13905, paras. 78-80 and C-399/11 Melloni, ECLI:EU:C:2013:107, paras. 37 and 63.
} 
reason to emphasise that mutual trust does not mean "blind trust", but instead trust must be earned and be based on the member state complying with the level of human rights' protection required by the EU. ${ }^{56}$ Paragraph 191 in Opinion 2/13 has also been referenced in legal literature, when there has been the need to emphasise the normative function of mutual trust. ${ }^{57}$

In the N.S. case the Court hold that the member state, which according to the Dublin II Regulation is responsible for examining applications for asylum, is responsible to observe the fundamental rights of the European Union. Thereafter, the Dublin II Regulation was revoked, and nowadays according to Article 3(2) of the Dublin III Regulation (EU) N:o 604/2013 ${ }^{58}$ member states may not transfer asylum seekers to the member state responsible for processing the asylum applications, if the shortcomings concerning the relevant member state's asylum procedure and reception conditions are such that the asylum seeker would be treated in an inhumane and degrading manner, as referred to in Article 4 of the Charter of Fundamental Rights of the European Union. On the other hand, in the Melloni case it is essential to recognise that relying on the national constitutional laws cannot weaken the influence of EU law in the territory of this member state. The national level of protection of people's fundamental rights can be applied in member states, subject to the fact that such application does not compromise the level of protection confirmed in the Charter of Fundamental Rights, or the primality, uniformity and efficiency of EU law. ${ }^{59}$

Particularly German literature has demonstrated that rights inferable from EU citizenship should be interpreted at a wider level to be part of the ensemble of EU human rights, and when EU citizens rely on their rights that are based on EU law, against national law, it is a case of reverse Solange doctrine. ${ }^{60}$ Originally the Solange doctrine referred to the case where the German Constitutional Court, in connection with the Internationale Handelsgesellschaft case ${ }^{61}$, considered it was competent to assess

\footnotetext{
56 See Lenaerts, K (2017), La vie après l'avis: Exploring the principle of mutual (yet not blind) trust, Common Market Law Review 54, 805-840, at 838. Lenaerts emphasises that, in terms of the efficiency of the principle of mutual trust and the protection of human rights, it is significant that the European Court of Human Rights, the Court of Justice of the European Union and national courts of justice engage in constructive dialogue. On the other hand, both the EU and member states must prepare trust-enhancing legislation, which maintains this mutual trust.

${ }^{57}$ See Bieber 2015, p. 38.

${ }^{58}$ See the European Parliament's and Council's Regulation (EU) N:o 604/2013, issued on 26th June 2013, stablishing the criteria and mechanisms for determining the Member State responsible for examining an application for international protection lodged in one of the Member States by a third-country national or a stateless person, OJ, N:o L 180, 29.6.2013, p. 31, particularly p. 41. Originally the so-called Dublin Agreement is in the background of the Dublin system, i.e. the Convention determining the State responsible for examining applications for asylum lodged in one of the Member States of the European Communities, OJ, N:o C 254, 19.8.1997, p. 1.

59 See C-399/11 Melloni, the judgment has been issued on 26th February, not published in the ECR, ECLI:EU:C:2013:107, Sections 59 and 60.

60 See Von Bogdandy - Antpöhler-Ioannidis 2017, at 219-220.

${ }^{61}$ See 11/70 Internationale Handelsgesellschaft (1970) ECR 1125.
} 
the harmony of the economic community's legal regulations in comparison to the fundamental rights protected by the German constitution, to the extent that the integration of the economic community ("solange") has progressed so far as to the community law including codification on fundamental and human rights that satisfies German fundamental rights. ${ }^{62}$

The reverse Solange doctrine is demonstrated by referring to the Zambrano case ${ }^{63}$, where the Court of Justice of the European Union ascertained, pursuant to TFEU Article 20, a permit to reside to a minor who had EU citizenship, in the member state in which the minor had citizenship. In the case, the parents of the child were nationals of a non-member country. According to the Court of Justice of the European Union, the position of a union citizen is so "fundamental" that TFEU Article 20 prevents such national procedures, which would result in EU citizens not being able to exercise the majority of the rights that they have on the basis of EU citizenship (genuine enjoyment test). ${ }^{64}$ In the Zambrano case, minors would have had to the leave the European Union with their parents, if the parents were not issued a permit to reside or a work permit. However, no far-fetching conclusions should be made on the reverse Solange doctrine, since it is connected to the rights inferable from EU citizenship and thus is not applicable to a very extensive ensemble of fundamental and human rights. ${ }^{65}$ As such, it does however create a worthwhile perspective for the topical academic debate concerning the principle of mutual trust.

From more recent case-law, the Aranyasi case can be brought up, in regards to which legal literature has assessed that the principle of mutual trust has a regulatory significance as the projection of the values underpinning the area of freedom, security and justice. ${ }^{66}$ The Court of Justice of the European Union stated, in context with the European Arrest Warrant, that the principle of mutual recognition is based on the member states' mutual trust concerning the fact that national legal systems are capable of ensuring the equal and efficient protection of their fundamental rights as recognised at a union

\footnotetext{
${ }^{62}$ See Solange I case Internationale Handelsgesellschaft mbH v Einfuhr- und Vorratsstelle für Getreide und Futtermittel, 29 May 1974, (1974) 2 CMLR 540 and respectively 2 BvL 52/71, BVerfGE 37, 271 and Davies, B, (2017), Internationale Handelsgesellschaft and the Miscalculation at the Inception of the ECJ's Human Rights Jurisprudence, in publication Nicola, F - Davies, B (eds.): EU Law Stories, Contextual and Critical Histories of European Jurisprudence (Cambridge, Cambridge University Press) 157-177, at 163.

${ }^{63}$ See C-34/09 Zambrano (2011) ECR I-1177.

${ }^{64}$ Ibid., Sections 42-44 and C-434/09 McCarthy (2011) ECR I-3375, Sections 45-47 and Raitio 2016, p. 519.

${ }^{65}$ See also Von Bogdandy - Antpöhler-Ioannidis 2017, p. 220, which states that, as of now, the Court of Justice of the European Union has not specifically linked rights inferable from EU citizenship and human rights in the manner required by the Solange doctrine.

${ }^{66}$ See Weller, M, (2017) Mutual trust within judicial cooperation in civil matters: a normative cornerstone - a factual chimera - a constitutional challenge, Nederlands internationaal privaatrecht, 1-21.
} 
level and particularly in the Charter of Fundamental Rights. ${ }^{67}$ In the way of the Court of Justice of the European Union, it is worth emphasising in terms of the mutual trust between member states, that all member states observe the union law, particularly the fundamental rights recognised in EU law. Thus, the concept of rule of law only acquires interpretative content in EU Law in connection with, how democracy and fundamental rights are implemented, and how member states can trust the legal systems of each other.

The same requirement for mutual trust between member states is also indicated in the directives concerning the development of an area of freedom, security and justice. It is a question of the efficiency of enforcing EU judicial objectives, standards and decisions in member states. For example, mutual recognition of decisions in criminal matters can only be efficiently achieved by relying on mutual trust. Both judicial authorities and other parties involved in the criminal procedure must be able to consider the decisions of other member states' judicial authorities as equal to decisions in their own member state. ${ }^{68}$ It is also a case of trust in the fact that another member state shall apply these key legal guarantees correctly, i.e. observation must not simply be allowed to remain at the level of provisions' comparisons. Strengthening mutual trust is subject to detailed provisions on the protection of procedural rights and warranties defined ${ }^{69}$ in the Charter of Fundamental Rights, the European Convention on Human Rights and ICCPR. ${ }^{70}$ In this respect, it is essential that a value base in accordance with Article 2 TEU is achieved in each member state.

\section{Conclusions}

My intention has been to advocate the "triangle of EU values", namely rule of law, democracy and human rights. In this respect, there is reason to refer to the Venice Commission's report concerning

\footnotetext{
${ }^{67}$ See C-404/15 \& C-659/15 PPU, Aranyosi, the judgment has been issued on 5th April 2016, not published in the ECR, ECLI:EU:C:2016:198, Section 77. It is to be mentioned that, at his lecture at the highest administrative court 24th May 2017, the President of the Court of Justice of the European Union Lenaerts particularly emphasised the link between Section 191 of Opinion 2/13 and e.g. the Aranyosi case in the interpretation of the concept concerning mutual trust between member states. This is also natural due to the fact that Section 191 of Opinion 2/13 is cited in Section 78 of the Aranyosi case.

${ }^{68}$ See the Directive of the European Parliament and of the Council 2012/13/EU, issued on 22nd May 2012, on the right to information in criminal proceedings, OJ, N:o L 142, 1.6.2012, p. 1-10, Introduction Section 4.

${ }^{69}$ International Covenant on Civil and Political Rights, 8/1976.

${ }^{70}$ See the Directive of the European Parliament and of the Council 2013/48/EU, issued on 22nd October 2013, the right to be assisted in criminal proceeding and in proceedings concerning the European Arrest Warrant as well as the right to be inform their arrest or detention to a third party and be in contact with a third parties and consular authorities during arrest or detention, OJ, N:o L 294, 6.11.2013, s. 1-12, Introduction Section 9.
} 
the rule of law ${ }^{71}$, wherein the rule of law is strongly connected to democracy and the requirement of the implementation of human rights. The discourse concerning the rule of law in the EU can, therefore, not be separated from the democracy that creates an environment of interpretation for the rule of law, distribution of power and the legal principles and human rights that legitimize the judicial system. In this context, the principle of the rule of law is not merely a "rhetorical balloon". The concept of the rule of law becomes a type of value-based ideal, according to which the development of societies is measured. ${ }^{72}$ In terms of this article, it is essential that the existence of the material concept of the rule of law has not been denied, when recent legal literature has specified the tensions between the formal and material concept of the rule of law. ${ }^{73}$

\section{Juha Raitio}

\footnotetext{
${ }^{71}$ See European Commission for Democracy Through Law (Venice Commission), Report on the Rule of Law, Adopted by the Venice Commission at its 86th plenary session, Venice 25-26 March 2011, Strasbourg, 4 April 2011, Study No. 512/2009, CDL-AD(2011)003rev.

${ }^{72}$ See McCorquodale 2016, 284-285.

73 See Konstadinides, T (2017) The Rule of Law in the European Union, (Oxford: Hart Publishing). 55-61, where Konstadinides specifies the Rule of Law with the help of the pair of concepts thin/thick Rule of Law.
} 